\title{
Dating of Soils on the Raised Coral Reef Terraces of Kikai Island in the Ryukyus, Southwest Japan : With Special Reference to the Age of Red-Yellow Soils
}

\author{
Shizuo Nagatsuka*1 and Yuji Maejima*2
}

\begin{abstract}
Absolute ages of soils developed on the raised coral reef terraces in Kikai Island were estimated by using the mean rate of tectonic uplift and glacio-eustatic curve during late Quaternary. The results obtained are as follows :

State of bare rock outcrop continues for $c a .1 .5 \mathrm{ka}$ after the emergence, and it takes ca. $3.0 \mathrm{ka}$ to develop Lithosols. Initial Rendzina-like soils (Rendzic Leptosols, Lithic Rendolls) begin to develop 3.5-3.9 ka after the emergence, and the soils of $35-40 \mathrm{ka}$ of age are Rendzina-like soils (Rendzic Leptosols, Lithic Rendolls). The soils of 50-55 ka of age have changed into Brown Rendzina-like soils (Mollic Leptosols, Eutropeptic Rendolls). At the point of time $70-80 \mathrm{ka}$ from the emergence, free calcium carbonate has already been leached out from solum, humus decomposition and clay migration have started, and Terra fusca-like soils (Haplic Luvisols, Typic Hapludalfs) are formed. After $95-100 \mathrm{ka}$ from the emergence, rubefaction (reddening) proceeds and the soils become to Terra rossa-like soils (Chromic Luvisols, Typic Hapludalfs). The soils of $120-125 \mathrm{ka}$ of age have an intermediate properties between Terra rossa-like soils and Red-Yellow soils (Haplic Lixisols, Typic Hapludalfs), although the degree of base saturation is in the proximity of Red-Yellow soils. Therefore, it is concluded that it will take ca. $125 \mathrm{ka}$ for Red-Yellow soils (Acrisols, Hapludults) to develop on coral limestone in the humid subtropical rain forest climate region.
\end{abstract}

Key Words : Coral limestone terrace, Kikai Island, Pleistocene, Red soil, Soil age

\section{Introduction}

Since Ohmasa et al. (1957) proved that the red soils (Acrisols, Udults) of Japan are considered to be relics of paleosols formed in the geological past, probably between late Pliocene and early Pleistocene, several different views have been proposed with regard to the age of red soils of Japan. Using morpho-stratigraphical and tephrochlonological methods, Matsui and Kato (1962) assigned the age of fossil red soils around Chikugo Plain, Northern Kyushu, to the last interglacial epoch (Riss/Würm) or interstadial stage. On the other hand, Kidachi and Ohmasa (1963) conceived that Günz/ Mindel interglacial epoch is the more probable period of red soil formation. These studies, however, do not deal with how many years does it take for the red soils to develop. It seems fundamentally important to determine the absolute age of the red soils and the process of red soil formation not only for pedological study but also for the significance of paleo-red soils to the Quaternary studies.

The objective of this study is to determine the absolute soil ages in a chronosequence developed on the raised coral reef terraces in Kikai Island by using a combined method of

Received June 4, 2000. Accepted October 28, 2000.

* 1 Institute of Applied Biochemistry, Tsukuba University. 1-1-1 Tennoudai, Tsukuba, 305-0006 (Present address : Japan Soil Research Institute Inc. Hibarigaoka Takano Bd. 7 F, 2-15-11 Yato-cho, Nishi-Tokyo, 188-0001, Japan). E-mail :

* 2 Research Fellow of the Japan Society for the Promotion of Science. Institute of Applied Biochemistry, Tsukuba University. 1-1-1 Tennoudai, Tsukuba, 305-0006, Japan. 


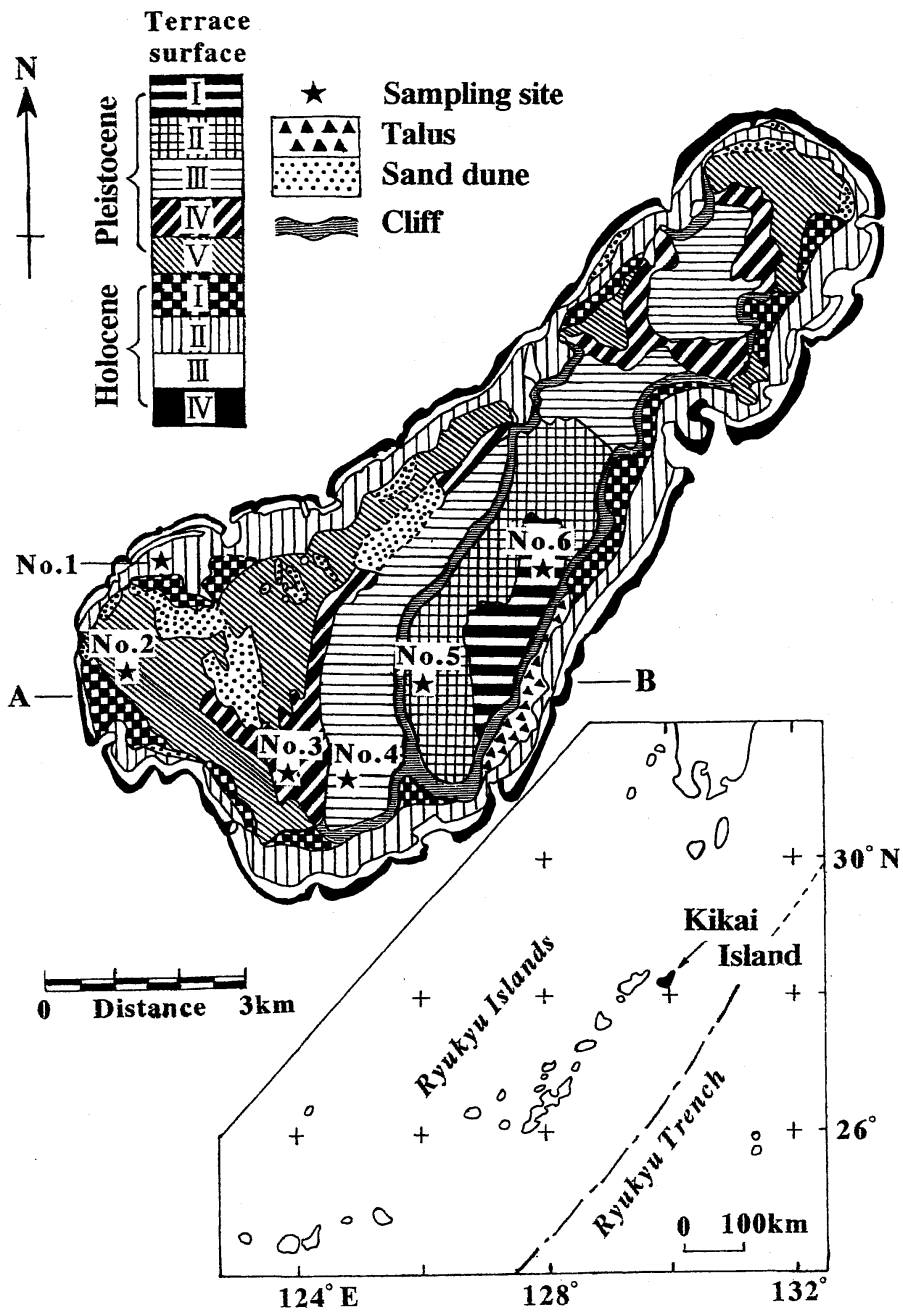

Fig. 1 Topography and soil sampling sites of Kikai Island

the mean rate of tectonic uplift and the glacioeustatic curve during late Quaternary, and finally to estimate the absolute age of the red soils.

\section{Soil-forming Factors of Kikai Island}

Kikai Island, located between latitudes $28^{\circ} 17^{\prime}$ and $28^{\circ} 23^{\prime} \mathrm{N}$, and longitudes $129^{\circ} 54^{\prime}$ and $130^{\circ} 03^{\prime}$ $\mathrm{E}$, is in the subduction zone where the Philippine Sea Plate is being consumed beneath the Eurasian Plate (Fig. 1). The island is also well known as an island that has continuously been lifted up with the high uplift rate of $c a .1 .8 \mathrm{~m} /$ ka during the past $120-130 \mathrm{ka}$ (Ota and Omura, 1992). It is also noted that Kikai Island is the only one in the Ryukyus that is fringed by Holocene raised coral reefs (Ota et al., 1978).

According to the meteorological data observed at Seiwa sugar-mill from 1966 to 1990 , the mean annual temperature is $22.3^{\circ} \mathrm{C}$ and the annual precipitation is $2,277 \mathrm{~mm}$. The warmthindex and the humidity-index is $208^{\circ} \mathrm{C}$ month and 13.0 , respectively, belonging to the humid subtropical rain forest climate defined by Kira (1949). The average of water deficit from 1941 to 1970 was $25 \mathrm{~mm} / \mathrm{yr}$ (Urushibara-Yoshino, 1988).

Former natural vegetation was a subtropical evergreen forest consisting mainly of evergreen broad-leaved trees and shrubs such as 
Ficus microcarpa, F. virgata, Viburnum suspensum, V. odoratissimum var. awabuki etc., however, it has been mostly cleared to sugarcane field and is now limited to very small area on the terrace cliffs.

The island consists of coral limestones from late Pleistocene to Holocene which discontinuously overlie the basement of early Pliocene siltstone, Somachi Formation. The coral limestones constitute a flight of raised coral reef terraces, and the ages of fossil corals from these coral limestones have been well established based on radiometric dating (Konishi et al., 1974).

According to Ota and Hori (1980), the raised coral reef terraces of Pleistocene are divided into five surfaces of I ( $224-190 \mathrm{~m}$ a.s.l.), II (190 $110 \mathrm{~m}$ a.s.l.), III ( $110-50 \mathrm{~m}$ a.s.1.), IV (50-35 m a.s. 1.) and $\mathrm{V}(35-20 \mathrm{~m}$ a.s.1.). On the other hand, the raised coral reef terraces of Holocene are divided into Holocene $\mathrm{I}(15-10 \mathrm{~m}$ a.s.l., ca. 6.8-6 ka), Holocene II $(7-5 \mathrm{~m}$ a.s.l., ca. $5.2-3.5 \mathrm{ka})$, Holocene III $(5-3 \mathrm{~m}$ a.s.l, $c a .3 .5-3 \mathrm{ka})$, and Holocene IV (2-1.5 $\mathrm{m}$ a.s.l., ca. $2.5-1.5 \mathrm{ka}$ ) (Ota et al., 1978). According to Konishi et al. (1974), all the high stillstands of sea-level younger than the last interglacial maximums are preserved in this island, and the highest point at $224 \mathrm{~m}$ a.s.l. is underlain by the reef limestone of Isotope Stage $5 \mathrm{e}$ (weighted average ${ }^{230} \mathrm{Th} /{ }^{234} \mathrm{U}$ age is $129 \pm 2 \mathrm{ka}$ ). This tectonic and geomorphological setting as well as coral-limestone chronology of Kikai Island gives a suitable field for the study of soil development on coral limestone and for the determination of absolute age of soil.

\section{Materials and methods}

In order to determine and compare the soils on the different terrace surfaces, soil survey was made on each surface of the abovementioned Pleistocene and Holocene terraces. As it is generally recognized that the depth of solum at former reef ridges is thinner than that of solum at former lagoon area, soil profiles used for comparison were taken at the former ridges on each of the terrace surfaces. Soil samples were taken from each horizon of the soil profiles and were used for physicochemical analyses. The glacio-eustatic curve during late Quaternary proposed by Konishi et al. (1974) based on radiometric ages of corals from Kikai Island, and the mean rate of tectonic uplift reported by Ota and Omura(1992) were used for the estimation of absolute soil age.

\section{Results and discussion}

\section{Soil distribution pattern on the raised} coral reef terraces

Soil distribution pattern in Kikai Island shows that a series of soils developed on the sequence of raised coral reef terraces constitutes a soil chronosequence and each member of the soil chronosequence represents a different stage of soil development or a different phase of soil evolution on coral limestone (Fig. 2). Relations among soils and the terrace plains are as follows :

\section{1) Bare rock outcrop on Holocene IV}

Neither soil development nor vegetation cover is recognized by the naked eye on this surface.

\section{2) Lithosols on Holocene III}

Dwarf shrubs (Limonium wrightii etc.) and sod grass (Zoysia tenuifolia) are sporadically grown on calcareous sand deposited in fissures or small solution pans (kamenitza) on the coral limestone. Very weakly developed thin (A)-horizon with $1-2 \mathrm{~cm}$ thick directly overlies on the parent rock. The soils on this surface are classified as Coral Limestone Lithosols (Lithic Leptosols; Lithic Entisols).

\section{3) Initial Rendzina-like soils on Holocene} II (No. 1)

Location : Kikai-jima marine park, altitude $5 \mathrm{~m}$ a.s.1. Vegetation: Ever-green shrubs (Scaevola taccada, Rhaphiolepis Umbellata), Pandanus odoratissimus, Miscanthus sinensis, Casualina equisetifolia etc.

\section{Profile description :}

Ah 1 (0-15 cm) : Brownish black (7.5 YR 2/2), high organic matter, clay loam to light clay with moderate medium granular and strong fine granular structure, many rounded gravel of coral limestone, sticky and plastic, hardness 14 , many very fine to fine and few medium roots, moderately moist, irregular diffuse boundary.

Ah 2 (15-30 cm) : Brownish black (10 YR 3/2), high organic matter, clay loam with strong fine crumb structure, common subangular large stone to boulder of coral limestone, sticky and plastic, hardness 12 , many very fine to fine and few medium roots, few fine pore on peds, moderately moist, irregular or wavy clear 
A

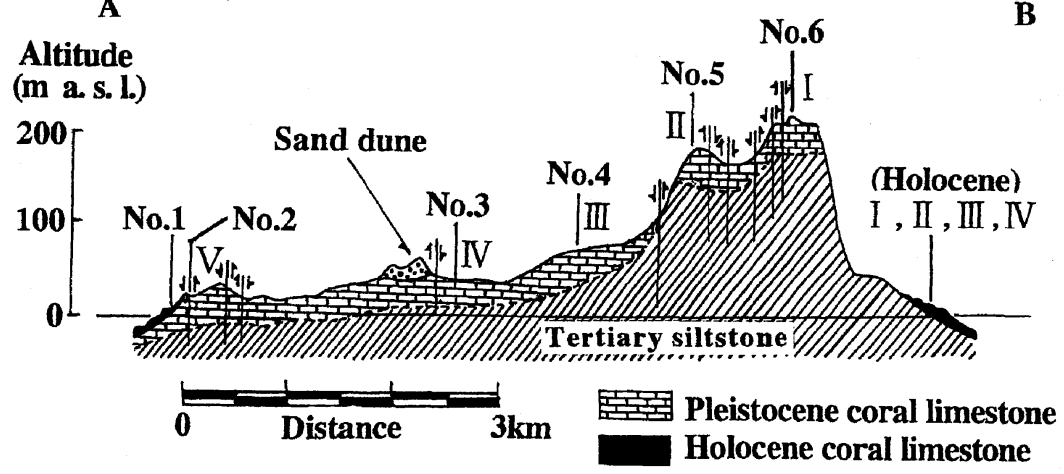

Fig. 2 Topography and geology along line A-B (Fig. 1) Modified from Ota and Omura (1992).

boundary.

$\mathbf{R}(\mathbf{3 0} \mathbf{c m}+)$ : Few very fine roots penetrating into parent rock.

\section{4) Rendzina-like soil on Pleistocene V}

(No. 2)

Location : About $250 \mathrm{~m}$ to the northwest of Araki shrine, altitude $27 \mathrm{~m}$ a.s.l.

Vegetation : Miscanthus sinensis, Messerschmidia argentea, Hibiscus rosasinensis, Mallotus japonicus, Argusia argentea.

\section{Profile description :}

Ah 1 (0-9 cm) : Brownish black (10 YR 3/2), very high organic matter, heavy clay with moderate to strong fine to medium subangular blocky structure, many fine gravel of coral, sticky and very plastic, hardness 18 , many very fine, fine to medium and few coarse roots, moderately moist, smooth diffuse boundary.

Ah 2 (9-23 cm) : Brownish black (10 YR 3/2), very high organic matter, heavy clay with moderate to strong fine subangular blocky structure, common weathered gravel and few powdery fragments of coral, sticky to very sticky, very plastic, hardness 21 , abundant very fine to fine, many medium and few coarse roots, few continuous medium pores on peds, moderately moist, smooth diffuse boundary.

AC (23-32 cm) : Dark brown (10 YR 3/3.5), medium organic matter, heavy clay with moderate fine to medium subangular blocky structure, common weathered gravel and few fragments of coral, sticky to very sticky, very plastic, hardness 23 , abundant very fine to fine, many medium and few coarse roots, few continuous medium pores on peds, moderately moist, irregular clear boundary.

C $(\mathbf{3 2}-\mathbf{7 0} \mathbf{~ c m})$ : Weathered coral limestone.

R $(\mathbf{7 0} \mathbf{c m}+)$ : Fresh coral limestone.
5) Brown Rendzina-like soil on Pleistocene IV (No. 3)

Location : About $500 \mathrm{~m}$ to the northeast of Tekutsuku. altitude $30 \mathrm{~m}$ a.s.l. gently sloping to the southwest.

Vegetation : Cycas revoluta, Lonicera sp., Miscanthus sinensis.

\section{Profile description :}

Ah 1 (0-12 cm) : Dark brown (7.5 YR 3/3), high organic matter, heavy clay with strong fine granular and nutty structure, common weathered large stone of coral limestone, sticky and plastic, hardness 11, many coarse to medium roots and common very fine to fine roots, many medium and common fine pores, moderately dry, smooth diffuse boundary.

Ah 2 (12-30 cm) : Dark brown (7.5 YR 3/4), medium organic matter, heavy clay with moderate fine subangular blocky structure, common weathered large stone of coral limestone, sticky and very plastic, hardness 14 , common very fine to fine roots, many medium and common fine pores, moderately moist, slightly wavy gradual boundary.

Bw (30-50 cm) : Dark reddish brown (6.25 YR 3.5/6), low organic matter, heavy clay with moderate fine to medium subangular blocky structure, common weathered large stone of coral limestone, very sticky and very plastic, hardness 23 , common fine, medium and coarse roots, many medium and common fine pores on peds, moderately moist, smooth gradual boundary.

C $(\mathbf{5 0}-\mathbf{7 0} \mathbf{c m})$ : Weathered coral limestone, smooth diffuse boundary.

$\mathbf{R}(\mathbf{7 0} \mathbf{c m}+)$ : Fresh coral limestone.

6) Terra fusca-like soil on Pleistocene III (No. 4) 
Location : About $500 \mathrm{~m}$ to the southwest of Kawamine. altitude $65 \mathrm{~m}$ a.s.l. slightly sloping to the NNW. Vegetation : Miscanthus sinensis, liana, Calystegia sp. Profile description :

A $(\mathbf{0}-\mathbf{1 0} \mathbf{c m})$ : Brown (7.5 YR 4/3.5), high organic matter, light clay with strong fine angular blocky structure, many weathered gravel of coral, sticky and plastic, hardness 12 , many very fine and common medium roots, dry, slightly wavy clear boundary.

Bt 1 (10-33 cm) : Brown (7.5 YR 4/6), medium organic matter, heavy clay with strong medium to fine angular blocky structure, many weathered gravel of coral and few sand grain of foraminifera, very sticky and very plastic, hardness 20 , many very fine to fine and few medium roots, few fine pores, faint clay cutan on peds, few speckled manganese mottles (7.5 YR 3/3) and few cloudy iron mottles, dry, smooth diffuse boundary.

Bt $2(33-65 \mathrm{~cm})$ : Brown (7.5 YR 4/6), low organic matter, heavy clay with strong medium to coarse angular blocky structure, many large stones of coral limestone, very sticky and very plastic, hardness 21 , many very fine to fine and few medium roots, few medium pores, distinct clay cutan on peds, few rootlike manganese mottles (7.5YR 4/4) and faint iron mottles, moderately dry, smooth gradual boundary. BC $(\mathbf{6 5}-\mathbf{8 0} \mathbf{c m})$ : Reddish brown to brown (6.25 YR 4/ $6)$, low organic matter, heavy clay with moderate medium to fine angular blocky structure, abundant weathered stones of coral limestone, very sticky and very plastic, hardness 17 , few very fine roots, few distinct clay cutan on peds, moderately moist, diffuse boundary.

$\mathbf{R}(\mathbf{8 0} \mathbf{c m}+)$ : Fresh coral limestone.

7) Terra rossa-like soil on Pleistocene II (No. 5)

Location : About 1,250 m to the south of Gusuku, Kawashiro district. altitude $186 \mathrm{~m}$ a.s.l. flat.

Vegetation : Pinus luchuensis, Miscanthus sinensis, dwarf bamboo, Cycas revoluta, Calystegia sp.

Profile description :

Oi $(+2.5-0 \mathrm{~cm})$ : litter.

A (0-12 cm) : Brownish black (5 YR 3/1), high organic matter, heavy clay with strong medium granular and medium to fine angular blocky structure, very sticky and very plastic, hardness 18 , abundant very fine to fine roots and few medium to coarse roots, moderately dry, smooth clear boundary.

Bt 1 (12-25 cm): Dark reddish brown (5 YR 3/6), medium organic matter, heavy clay with strong medium to fine angular blocky structure, abundant distinct sesquioxide cutan on peds, very sticky and very plastic, hardness 21 , abundant very fine to fine roots and few medium roots, few very fine pores, moderately moist, smooth gradual boundary.

Bt 2 (25-46 cm) : Reddish brown (6.25 YR 4/6), heavy clay with strong medium to fine angular blocky structure, abundant distinct sesquioxide cutan on peds, very sticky and very plastic, hardness 23 , many very fine to fine roots and few medium roots, few medium pores, few manganese mottles, moderately moist, smooth diffuse boundary.

Bt 3 (46-58 cm) : Reddish brown (6.25 YR 4/6), heavy clay with strong medium to fine angular blocky structure, abundant distinct sesquioxide cutan on peds, very sticky and very plastic, hardness 21 , many very fine to fine roots, few fine pores on peds, very few speckled manganese mottles and many cloudy iron mottles (5 YR 4/6), moderately moist, smooth diffuse boundary.

BC 1 (58-72 cm) : Bright brown (7.5 YR 5/7), low organic matter, heavy clay with moderate medium to fine angular blocky structure, very sticky and very plastic, hardness 21, many very fine to fine roots, very few speckled manganese mottles and common to many cloudy iron mottles (5 YR 4/6), few distinct clay cutan on peds, moderately moist, smooth diffuse boundary.

BC 2 (72-85 cm) : Dark brown (7.5 YR 3/4), low organic matter, heavy clay with moderate medium to fine angular blocky structure, common gravels of coral limestone, very sticky and very plastic, hardness 19 , common very fine roots, common speckled manganese mottles and common cloudy iron mottles (7.5 YR 4/6), few distinct clay cutan on peds, moderately moist.

8) Intergrade between Terra rossa-like and Red-Yellow soil on Pleistocene I (No. 6)

Location : Hyakunodai, near the stone triangulation marker. altitude $200 \mathrm{~m}$ a.s.l. slightly sloping to the north.

Vegetation : Ever-green broad-leaved shrubs, Rhaphiolepis umbellata, Leucaena leucocephala, Miscanthus sinensis, fern, Ligularia tussilaginea.

Profile description :

Oi $(+\mathbf{0 . 5}-\mathbf{0 ~ c m})$ : litter.

A $(\mathbf{0}-\mathbf{1 0} \mathbf{c m})$ : Dark brown (7.5 YR 3/4), high organic matter, heavy clay with moderate fine granular and weak fine sub-angular blocky structure, few fine angular gravels of coral limestone, sticky and very 
Table 1 Granulometric composition and organic matter content of the soils of Kikai Island

\begin{tabular}{|c|c|c|c|c|c|c|c|c|c|}
\hline Horizon & Depth & Sand** & Silt** & Clay** & Texture*** & $\mathrm{CaCO}_{3}$ & \multicolumn{2}{|c|}{ Org-C Total-N } & \multirow[t]{2}{*}{$\mathrm{C} / \mathrm{N}$} \\
\hline & (cm) & (-_._- & $-(\%)$ & $\ldots$ & & ב-ב_- & $-\left(\mathrm{g} \mathrm{kg}^{-1}\right)$ & $\ldots$ & \\
\hline & \multicolumn{9}{|c|}{ No.1 Initial Rendzina-like soil (Holocene II, $10 \mathrm{~m}$ a.s.l.) } \\
\hline Ahl & $0-15$ & 52.4 & 16.8 & 30.9 & $\mathrm{SC}$ or $\mathrm{LiC}$ & 13.3 & 129.4 & 12.2 & 10.6 \\
\hline \multirow[t]{2}{*}{ Ah2 } & $15-30$ & 61.6 & 16.1 & 22.3 & SCL & 22.0 & 83.7 & 7.9 & 10.6 \\
\hline & \multicolumn{9}{|c|}{ No.2 Rendzina-like soil (Pleistocene V, $27 \mathrm{~m}$ a.s.l.) } \\
\hline Ah1 & $0-9$ & 28.7 & 29.7 & 41.6 & $\mathrm{LiC}$ & 0.7 & 31.8 & 2.9 & 11.0 \\
\hline Ah2 & $9-23$ & 25.1 & 21.3 & 53.7 & $\mathrm{HC}$ & 0.2 & 22.7 & 2.0 & 11.3 \\
\hline \multirow[t]{2}{*}{ A3 } & 23-32 & 31.4 & 35.2 & 33.3 & $\mathrm{LiC}$ & 0.4 & 20.8 & 1.9 & 10.9 \\
\hline & \multicolumn{9}{|c|}{ No.3 Brown Rendzina-like soil (PleistoceneIV, $35 \mathrm{~m}$ a.s.1.) } \\
\hline Ah1 & $0-12$ & 11.1 & 23.0 & 65.9 & $\mathrm{HC}$ & 0.6 & 48.8 & 4.4 & 11.1 \\
\hline Ah2 & $12-30$ & 12.8 & 12.7 & 74.5 & $\mathrm{HC}$ & 0.5 & 18.5 & 1.7 & 10.9 \\
\hline \multirow[t]{2}{*}{ Bw } & $30-50$ & 6.2 & 13.8 & 80.0 & $\mathrm{HC}$ & 1.3 & 20.6 & 2.0 & 10.3 \\
\hline & \multicolumn{9}{|c|}{ No.4 Terra fusca-like soil (Pleistocene III, $85 \mathrm{~m}$ a.s.l.) } \\
\hline A & $0-10$ & 15.6 & 37.9 & 46.5 & $\mathrm{HC}$ & 13.2 & 48.3 & 3.8 & 12.7 \\
\hline Bt1 & $10-33$ & 8.3 & 21.6 & 70.1 & $\mathrm{HC}$ & 0.0 & 18.5 & 1.8 & 10.3 \\
\hline Bt2 & $33-65$ & 10.6 & 14.8 & 74.6 & HC & 0.1 & 13.8 & 1.4 & 9.8 \\
\hline \multirow[t]{2}{*}{$\mathrm{BC}$} & $65-80$ & 6.6 & 12.5 & 80.9 & $\mathrm{HC}$ & 1.5 & 17.6 & 1.8 & 9.8 \\
\hline & \multicolumn{9}{|c|}{ No.5 Terra rossa-like soil (Pleistocene II, $186 \mathrm{~m}$ a.s.l.) } \\
\hline A & $0-12$ & 14.6 & 28.7 & 56.7 & $\mathrm{HC}$ & 0.0 & 50.1 & 4.4 & 11.4 \\
\hline Bt1 & $12-25$ & 11.3 & 11.4 & 77.3 & $\mathrm{HC}$ & 0.3 & 14.7 & 1.4 & 10.5 \\
\hline $\mathrm{Bt} 2$ & $25-46$ & 11.5 & 12.7 & 75.8 & $\mathrm{HC}$ & $0.2^{\circ}$ & 10.3 & 1.1 & 9.4 \\
\hline Bt3 & $46-58$ & 14.2 & 14.5 & 71.3 & $\mathrm{HC}$ & 0.1 & 11.2 & 1.1 & 10.1 \\
\hline $\mathrm{BC} 1$ & $58-72$ & 14.0 & 18.6 & 67.4 & $\mathrm{HC}$ & 0.0 & 11.2 & 1.1 & 10.2 \\
\hline \multirow[t]{2}{*}{$\mathrm{BC} 2$} & $72-85$ & 6.4 & 12.0 & 81.8 & $\mathrm{HC}$ & 0.2 & 21.0 & 1.3 & 16.1 \\
\hline & \multicolumn{9}{|c|}{ No.6 Terra rossa-like/Red-Yellow soil (Pleistocene I, $200 \mathrm{~m}$ a.s.l.) } \\
\hline A & $0-10$ & 10.4 & 22.7 & 66.9 & $\mathrm{HC}$ & 0.1 & 45.0 & 3.3 & 13.6 \\
\hline $\mathrm{AB}$ & $10-28$ & 9.8 & 21.4 & 68.8 & $\mathrm{HC}$ & 0.1 & 25.5 & 2.2 & 11.6 \\
\hline Bt1 & $28-68$ & 7.3 & 7.2 & 85.5 & $\mathrm{HC}$ & 0.1 & 9.2 & 1.0 & 9.2 \\
\hline BD2 & $68-90$ & 7.2 & 13.1 & 79.7 & $\mathrm{HC}$ & 0.5 & 7.1 & 0.8 & 8.9 \\
\hline
\end{tabular}

plastic, hardness 12 , many very fine to fine roots and common medium roots, moderately dry, wavy clear boundary.

AB (10-28 cm) : Brown (7.5 YR 4/5), medium organic matter, heavy clay with moderate fine granular and weak fine sub-angular blocky structure, sticky and very plastic, hardness 16 , common very fine to fine roots and few medium roots, moderately dry, wavy gradual boundary.

Bt 1 (28-68 cm) : Bright reddish brown (5 YR 5/8), low organic matter, heavy clay with strong medium to fine angular blocky structure, distinct clay cutan on peds, common speckled manganese mottles and cloudy iron mottles (5 YR 4.5/8), sticky and very plastic, hardness 22 , common very fine to fine roots, moderately moist, smooth diffuse boundary.

Bt $2(68-90 \mathrm{~cm})$ : Bright brown (7.5 YR 5/8), low organic matter, heavy clay with moderate fine angular blocky and weak medium angular blocky structure, distinct clay cutan on peds, common speckled manganese mottles and many cloudy iron mottles (5 YR $4.5 / 8$ ), very sticky and very plastic, hardness 24 , few very fine to fine roots, few fine pore on peds, moderately moist, irregular clear boundary.

$\mathbf{C}(\mathbf{9 0} \mathbf{~ c m ~ + ) ~ : ~ W e a t h e r e d ~ c o r a l ~ l i m e s t o n e . ~}$

\section{Physico-chemical properties of soils}

Physico-chemical properties of the representative soil profiles are shown in Tables 1 and 2 .

Initial Rendzina-like soil (No. 1) contains considerable amount of free carbonate $(133-220$ 
Table 2 Physico-chemical properties of the soils of Kikai Island

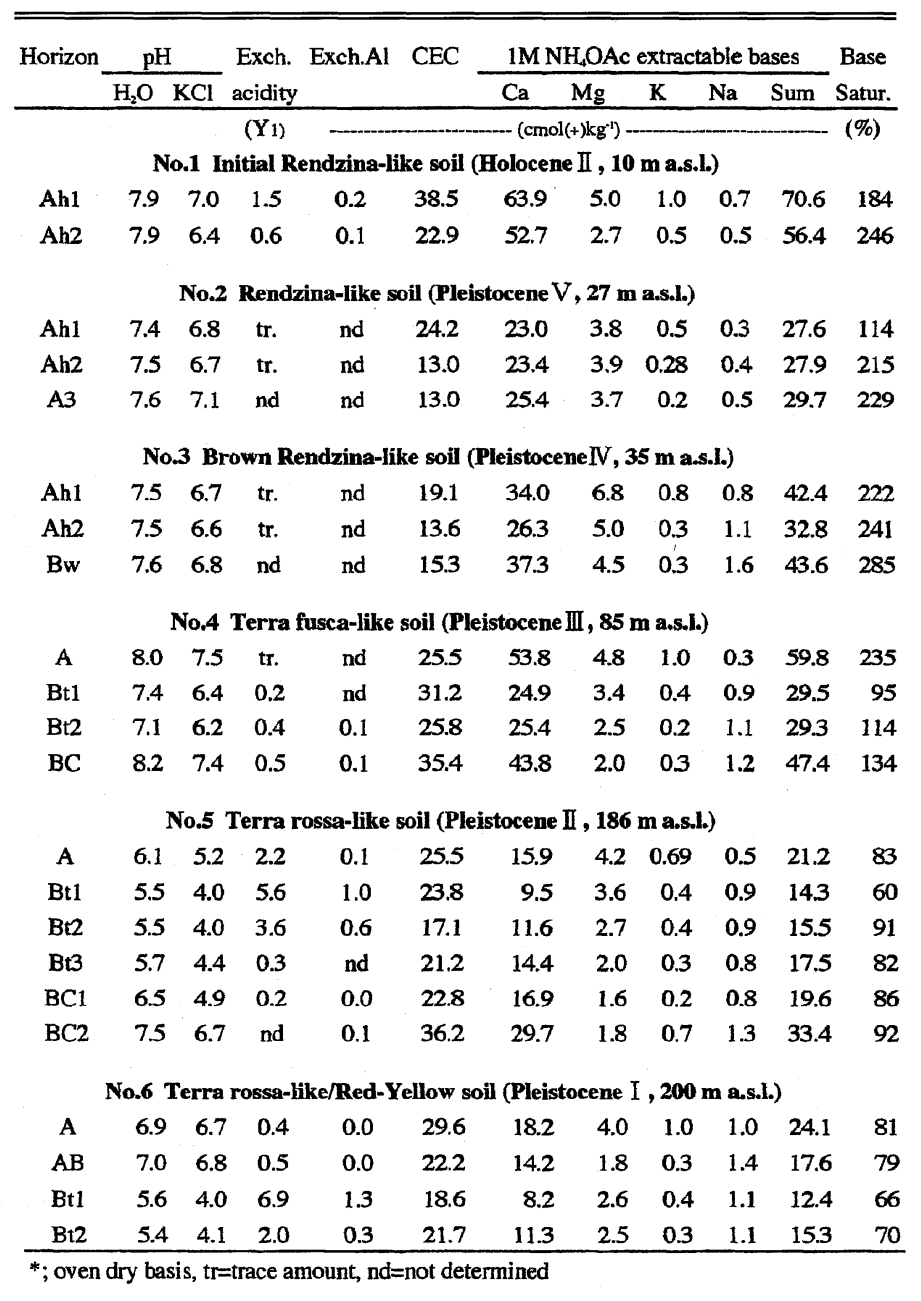

$\mathrm{gkg}^{-1} \mathrm{CaCO}_{3}$ ) and is characterized by high organic carbon content $\left(84-129 \mathrm{gkg}^{-1}\right)$, weakly alkaline reaction and relatively coarse texture.

In Rendzina-like soil (No. 2) free carbonate is mostly leached out from the solum and organic carbon content has decreased to less than 50 $\mathrm{gkg}^{-1}$, however, the exchange complexes are saturated.

Brown Rendzina-like soil (No. 3) shows a development of Bw-horizon, but the physicochemical properties are similar to those of Rendzina-like soil except that clay contents remarkably increased to $65.9-80.0 \%$ which increase with depth.

Terra fusca-like soil (No. 4) is characterized by well developed Bt-horizon in which clay cutan is clearly recognized on ped. Soil reaction is nearly neutral except for A- and BChorizons, and the exchange complexes are still in the state of saturation.

Terra rossa-like soil (No. 5) is also characterized by dark reddish brown to reddish brown Bt-horizon which shows maximum clay accumulation. Slight base unsaturation appears in the Bt-horizon of which soil reaction is weakly acidic.

The profile No. 6 on the highest terrace is morphologically resemble with that of RedYellow soils in Southwest Japan, however, the degree of base saturation is still in the range of $66-80 \%$, while that of Red-Yellow soils is less than $35 \%$. Therefore, this soil is considered to 
Table 3 Classification of studied pedons according to Unified Soil Classification System of Japan(1st Approximation, 1986) and the correlation with both WRB (1998) and Soil Taxonomy (1994)

\begin{tabular}{|c|c|c|c|}
\hline $\begin{array}{l}\text { Profile } \\
\text { No. }\end{array}$ & $\begin{array}{c}\text { Japanese System } \\
(1986)\end{array}$ & $\begin{array}{l}\text { WRB } \\
(1998)\end{array}$ & $\begin{array}{l}\text { Soil Taxonomy } \\
\text { (1994) }\end{array}$ \\
\hline No.1 & Initial Rendzina-like soil & Rendzic Leptosol & Lithic Rendoll \\
\hline No.2 & Rendzina-like soil & Rendzic Leptosol & Lithic Rendoll \\
\hline No.3 & Brown Rendzina-like soil & Mollic Leptosol & Eutropeptic Rendoll \\
\hline No.4 & Terra fusca-like soil & Haplic Luvisol & Typic Hapludalf \\
\hline No.5 & Terra rossa-like soil & Chromic Luvisol & Typic Hapludalf \\
\hline No. 6 & $\begin{array}{l}\text { Terra rossa-like / } \\
\text { Red-Yellow soil }\end{array}$ & Haplic Lixisol & Typic Hapludalf \\
\hline
\end{tabular}

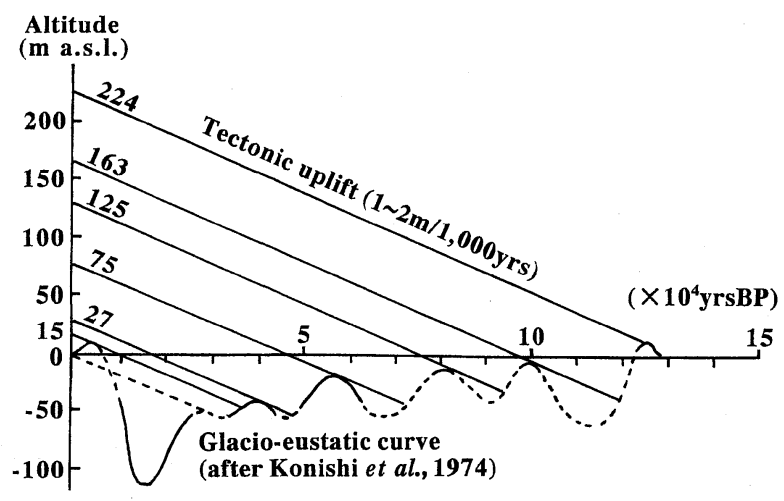

Fig. 3 Estimation of pedogenetic rate from tectonic uplift and eustatic curve

be intergrade between Terra rossa-like soils and Red-Yellow soils.

Based on these analytical data and profile morphology, the representative pedons were correlated with the taxon of WRB (FAO, ISRIC and ISSS, 1998) and Soil Taxonomy (Soil Survey Staff, 1994). The correlation is shown in Table 3.

\section{Estimation of absolute soil age}

It is generally difficult to determine the initiation time or starting point of time in soil development, because the formation time of parent rock or material and its time of exposure on the ground surface are not necessarily identical. It is rather rare that both of the times coincide with each other. In this study the initiation time in soil development was obtained as the time when the coral reef surface had finally emerged from under the sea level, and the absolute age of soil is expressed by the duration from the initiation time in soil development to the present.

Figure 3 illustrates how the initiation time and the absolute age of soil are graphically estimated. If a straight line is drawn from a given point of altitude on the ordinate parallel to the line of mean rate of tectonic uplift, the abscissa of the intersection of the straight line and the glacio-eustatic curve indicates the initiation time in soil development regarding to the soil located at the given altitude. For example, it is estimated that the soils distributed at $160 \mathrm{~m}$ to $224 \mathrm{~m}$ altitudes had emerged $125-$ $120 \mathrm{ka} \mathrm{BP}$ and the absolute age of soil is estimated to be ca. $125-120 \mathrm{ka}$. On the other hand, the soil located at the altitude a little 
Table 4 Soil development on raised coral reef terraces and the rate of soil formation

\begin{tabular}{|c|c|c|c|c|}
\hline Terrace & $\begin{array}{l}\text { Altitude } \\
\text { (m a.s.l.) }\end{array}$ & $\begin{array}{c}\text { Age of coral } \\
\left(\times 10^{4} \mathrm{yrsBP}\right)\end{array}$ & Genetic soil type & $\begin{array}{c}\text { Duration of soil } \\
\text { formation } \\
\left(\times 10^{4} \mathrm{yrsBP}\right)\end{array}$ \\
\hline \multicolumn{5}{|l|}{ Pleistocene } \\
\hline I & $224 \sim 190$ & 12.5 & $\begin{array}{l}\text { Terra rossa-like/ } \\
\text { Red-Yellow soil }\end{array}$ & $12.5 \sim 12.0$ \\
\hline II & $190 \sim 110$ & 10.0 & Terra rossa-like soil & $10.0 \sim 9.5$ \\
\hline III & $110 \sim 50$ & 8.0 & Terra fusca-like soil & $8.0 \sim 7.0$ \\
\hline IV & $50 \sim 35$ & $5.0 \sim 6.0$ & Brown Rendzina-like soil & $5.5 \sim 5.0$ \\
\hline $\mathrm{V}$ & $35 \sim 20$ & $3.6 \sim 4.5$ & Rendzina-like soil & $4.0 \sim 3.5$ \\
\hline \multicolumn{5}{|l|}{ Holocene } \\
\hline I & $15 \sim 10$ & $0.60 \sim 0.68$ & $(?)$ & 0.60 \\
\hline II & $7 \sim 5$ & $0.35 \sim 0.52$ & Initial Rendzina-like soil & $0.39 \sim 0.35$ \\
\hline III & 5 3 & $0.30 \sim 0.35$ & Lithosol & 0.30 \\
\hline IV & $2 \sim 1.5$ & $0.15 \sim 0.20$ & Rock land & 0.15 \\
\hline
\end{tabular}

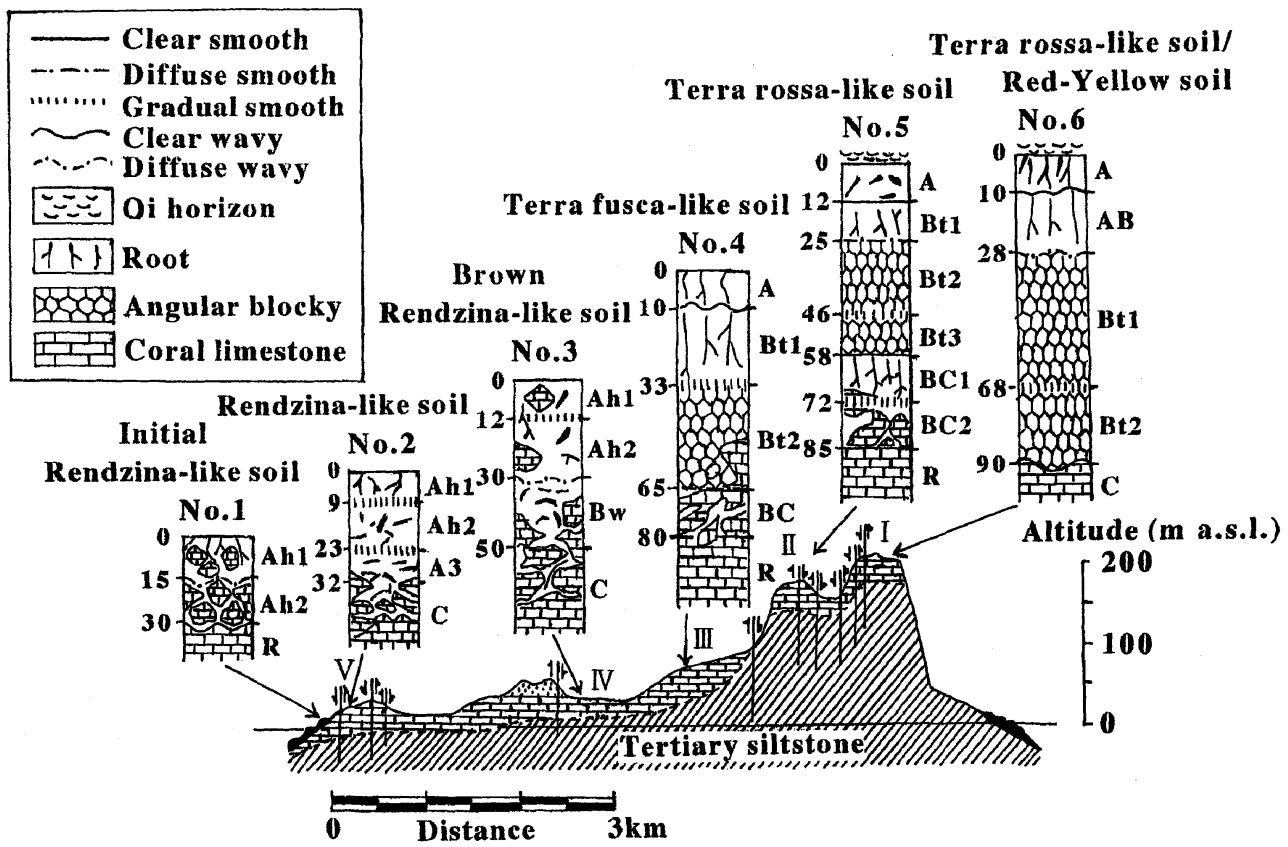

Fig. 4 Soil development on the raised coral reef terraces of Kikai Island

lower than $125 \mathrm{~m}$ a.s.l. is considered to have once emerged $c a .95 \mathrm{ka} \mathrm{BP}$, then it had submerged $c a$. $80 \mathrm{ka} \mathrm{BP}$, and again emerged thereafter. Therefore, the duration of soil formation that corresponds to the absolute soil age is estimated to be $c a .80 \mathrm{ka}$. The absolute ages of the representative soils thus estimated in this way are shown in Table 4.

\section{Conclusions}

From the foregoing it is concluded that the process of soil evolution on the raised coral reef terraces in the humid subtropical rain forest climate region proceeds step by step and the 
absolute ages of soil in each stage (Fig. 4) are estimated as follows :

1. State of rock outcrop continues for $c a$. $1.5 \mathrm{ka}$ after the emergence.

2. It takes about $3 \mathrm{ka}$ to develop coral limestone Lithosols.

3. After $3.5-3.9 \mathrm{ka}$ from the emergence, humus accumulation proceeds in the presence of free calcium carbonate, and Initial Rendzinalike soils (Rendzic Leptosols, Lithic Rendolls) are formed.

4. In the soils of $3.5-40 \mathrm{ka}$ of age, most of free calcium carbonate has been leached out from Ah-horizon and humus decomposition has started. Soils are developed into Rendzinalike soils (Rendzic Leptosols, Lithic Rendolls).

5. Soils of $50-55 \mathrm{ka}$ of age are changing into Brown Rendzina-like soils (Mollic Leptosols, Eutropeptic Rendolls). In this stage argillation (clay formation) proceeds but clay migration has not yet started.

6. After $70-80 \mathrm{ka}$ from the emergence clay migration has started and exchange acidity has slightly appeared, and soils develop into Terra fusca-like soils (Haplic Luvisols, Typic Hapludalfs).

7. After $95-100 \mathrm{ka}$ from the emergence, rubefaction (reddening) proceeds and the soils develop into Terra rossa-like soils (Chromic Luvisols, Typic Hapludalfs).

8. The soils of $120-125 \mathrm{ka}$ of age have an intermediate properties between Terra rossalike soils and Red-Yellow soils which are correlated with Haplic Lixisols or Typic Hapludalfs. In these soils leaching of exchangeable cations has considerablly proceeded, but degrees of base saturation except Bt 1-horizon are still remaining above $35 \%$. These soils are considered to be in the proximity of RedYellow soils.

Therefore, it is concluded that it will take $c a$. $125 \mathrm{ka}$ for Red-Yellow soils (Acrisols, Hapludults) to develop on coral limestone in the humid subtropical rain forest climate region.

\section{Acknowledgements}

The authors are grateful to Prof. Dr. K. Urushibara-Yoshino of Komazawa University (now Hosei University), Prof. Dr. T. Higashi and Dr. A. Tomikawa of Tsukuba University who co-operated in the field soil survey in Kikai Island. Thanks are equally due to Prof. Dr. Y. Ota of Yokohama National University (now Senshuu University) for her kind help to give the authors valuable geomorphological and geological information on Kikai Island. This study was financially supported by the Grantsin-Aid for Scientific Research, No. 04660067 from the Ministry of Education, Science and Culture of Japan.

\section{References}

FAO, ISRIC and ISSS (1998) World reference base for soil resources, world soil resources reports $84.88 \mathrm{p}$, FAO Rome.

Kidachi, M. and Ohmasa, M. (1963) Geological and mineralogical study on the formation of red soils in Japan. 126 p, Forest Soils of Japan (Rep. Gov. Forest Ex. St.), 14. (J+E)

Kira, T. (1949) Forest zones in Japan. 36 p, Ringyo Kaisetsu Series, No. 17, Nippon Ringyo Gijyutsu Kyokai. (J)

Konishi, K., Omura, A. and Nakamichi, O. (1974) Radiometric coral ages and sea level records from the late Quaternary reef complexes of the Ryukyu Islands. Proc. 2nd Intl. Coral Reef Symp., 2, Great Barrier Reef Comm. : 595-613, Brisbane.

Matsui, T. and Kato, Y. (1962) Notes on paleopedology of red soils in Japan. The Quat. Res. (DaiyonkiKenkyu), 2, 161-179. (J+E)

Ohmasa, M., Kurotori, T. and Kidachi, M. (1957) Studies of red soils of Japan I, Red soils of Niigata Prefecture. 126 p, Forest Soils of Japan (Rep. Gov. Forest Ex. St.), 8. (J+E)

Ota, Y. and Hori, N. (1980) Late Quaternary tectonic movement of the Ryukyu Islands, Japan. The Quat. Res. (Daiyonki-Kenkyu), 18, 221-240. (J+E)

Ota, Y., Machida, H., Hori, N., Konishi, K. and Omura, K. (1978) Holocene raised coral reefs of Kikai-jimaAn approach to Holocene sea level study-. Geographical Review of Japan (Chirigaku-Hyoron), 51, 109-130. (J+E)

Ota, Y. and Omura, A. (1992) Contrasting styles and rates of tectonic uplift of coral reef terraces in the Ryukyu and Daito Islands, Southwestern Japan. Quat. Intern., 15/16, 17-29.

Soil Survey Staff (1994) Keys to soil taxonomy, sixth edition. 306 p, U.S.D.A. Soil Conservation Service.

Urushibara-Yoshino, K. (1988) The red soils on a limestone area in Nansei-islands, Southwest Japan. Gillieson, D. and Smith, D. I. (eds.) "Resource management in limestone landscapes" Special Publication, No. 2 : 183-189, The Australian Defence Force Academy, Australia.

$(\mathrm{J})$ in Japanese, $(\mathrm{J}+\mathrm{E})$ in Japanese with English abstract 


\title{
喜界島の離水サンゴ礁段丘上に発達した土壤の年代測定 一とくに赤黄色土の絶対年代についてー
}

\author{
永 塚 鎮 男*1・前 島 勇 治*2
}

(要 旨)

わが国の古赤色土の生成時期に関しては，鮮新世末〜 更新世初期, 中期更新世, 後期更新世などの諸説があり, 未だ定説が得られていない．この問題を解決するために は, 赤色土の生成速度すなわち土壌が発達しはじめてか ら赤色土の状態に達するまでに要する時問を明らかにす ることが必要と考えられる. 本研究では, すでに多数の 化石サンゴの放射年代測定值に基づいて後期更新世の水 河性海面変動と平均隆起速度が明らかにされている喜界 島を対象として, 水河性海面変動曲線と平均隆起速度直 線を組み合わせた方法によって，離水サンゴ礁段丘上に 発達した土畩の絶対年代を推定することを試みた。 得ら れた結果は，以下のとおりである.

1. 離水後約 1,500 年間は土䁃生成はほとんど進行せ ず, 露岩地の状態が続く.

2. 約 3,000 年で (A)/R 断面を示す固結岩屑土がで きはじめる.

3. 約 3,500 3,900 年経過すると, 遊離の炭酸カル シウムの存在下で腐植集積作用が進行し, Ah/R 断面を 示す初生レンジナ様土が形成される.

4. 約 $35,000 \sim 40,000$ 年の土壤では, 遊離の炭酸力
ルシウムは Ah 層からほぼ完全に溶脱されるとともに, 腐植の分解が始まり, $\mathrm{Ah} / \mathrm{C} / \mathrm{R}$ 断面を示すレンジナ様土 になる.

5. 約 $50,000 \sim 55,000$ 年の土壌は $\mathrm{Ah} / \mathrm{Bw} / \mathrm{C}$ 断面を 示す褐色レンジナ様土に変化し, この段階では粘土化作 用が進むが，粘土の機械的移動は生じていない.

6. 約 70,000 80,000 年経過すると, 遊離の炭酸力 ルシウムは土層からほぼ完全に失われ, 腐植の分解之粘 土の機械的移動が進行し, $\mathrm{A} / \mathrm{Bt} / \mathrm{C}$ 断面を示すテラフス 力様土が生成する.

7. 約 $95,000 \sim 100,000$ 年経過すると，わずかに塩基 未飽和が現れるととあに，赤色化作用が進んでテラロッ サ様土が生成する.

8. 約 $120,000 \sim 125,000$ 年経過する之, 交換性陽イ オンの溶脱がかなり進行するが, 塩基飽和度はなお $35 \%$ より高く，テラロッサ様土と赤黄色土の中間的な土畩が 生成している.

以上の結果から, 湿潤亜熱帯多雨林気候地域の離水 サンゴ礁段丘上で赤黄色土が生成するためには，約 125,000 年の年月が必要と考えられる.

\footnotetext{
*1 筑波大学応用生物化学系 †305-0006 つくば市天王台 1-1-1 (現住所 : (有)日本土壤研究所 テ188-0001 西東京市谷戸 町 2-15-11. ひばりヶ丘高野ビル 7F). E-mail :

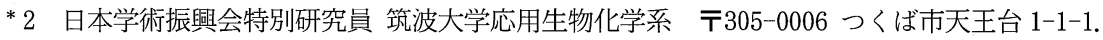

